\title{
ポリアミド樹 脂
}

緒言

ポりアミド樹脂はナイロンを先頭とする新興樹 脂でありアミド結合を以て構成されたる縮合系高 分子化合物の總稱である。この分野は未だ新しく ナイロン以外には二三の幾分詳細なる诟究か゚むる のみであり，從つて著するにあたり全醩を穊獺す ろ立場につとさるる何ナイロンが主題と成るは盐 し止むを得ないことと思ふ。豫め讀者の諒解を乞。 ふ二次第である。思ふに戰況は詩酷の一途を辿りつ つあり，今こそ吾が科學技術陣は利用價值ある凡 ゆろ人造物を以て, 㧟にその特徽を活用し, 兵器 に戰力の增强に資すべき秋である。小篇聊かなり とるこれが參考と成る所むらば著者の幸これにす ぎるものはない。

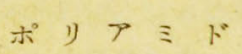

1923 年以來 Staudinger 一派の人々の合成化與 的方面よりの高分子化合物の研究之一方 Meyer, Mark, Hess, Treudenberg, Haworth Astburg 共D 他の人々の天然物の物理化學的, 化合的砳究に上 り今日は高分子に關する凡そ正湿を得た概念に到 達せることは既に成苩に見られることであり又低 分子化合物に見られない高分子の機械的特性け分 子の巨大性によるものなる事も今更說明する必要 がない。吾々が繊維に，皮膜可盕物にこれ等つ性 質を利用せるこよは古くより天然物に新しくは合 成高分子の别なき處である。かく高分子の性颀，化

\section{村橋 俊 介}

學槛造が次第に天然高分子，合成高分子に於て明 に应るに從つて合成一次元的な線狀高分子が織維 こして登場し始めた昭和13年には Synthofil, P.C Faser, Vinyarn (Vinyon) つづんて Nylon の出 現を見，合成織維が世の注目を惹くに到つた。記 述の順序として現在高分子合成方法としては次記 の三種が存在することを述へねばならない,゙古典 的な有機化學合成法による逐一の合成は數萬，数 十萬の分子是を有する巨大分子の合成に間に合は ない尃ら重合法によつて居る。重合なる概念は古 くから存在するが高分子化學つ弡達につれて其の 意義が重視され且里要なるのとなつた。現在行は れて居る重合の廣義解釋によれば多數の類似分子 が主原子價を以つて結合して一つメ分子を形成す ろ任意の化制的結合を謂ふのであつて

下㲹 (1), (2), (3) は何れもとの篹疅に入る

(1) はスチロールの重合であり多くの Vinyl 化 合物もこれと同樣な重合方法を取るるのである單

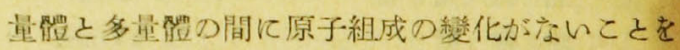
特徽とする故附加王合なる名稱の附上られて居る ものである。

（2）はポリアミド(線㹜)の生成であり(1)と 異なる點は鎻の生長はアミつ基 (官能基) カルボ キシル基 (官能基) 間にアミド結合の生成する事 により行はれ其の際1分子づつの水の排出をよも なふ-所謂縮合重合型式である縮合に際し排出する 低分子は官能基の種類により水とは限らない。

1)<smiles>C=CCCCCC(CC)CCCCCCCCCCCC</smiles>

2)

$$
\mathrm{H}_{2} \mathrm{~N}-\left(\mathrm{CH}_{2}\right)_{n}-\mathrm{NH}_{2}+\mathrm{COOH}\left(\mathrm{CH}_{2}\right)_{n} \cdot \mathrm{COOH} \longrightarrow
$$
$\left[\mathrm{NH}\left(\mathrm{CH}_{2}\right)_{n}-\mathrm{NHCO} \cdot\left(\mathrm{CH}_{2}\right)_{n}-\mathrm{CONH}\right]$

3)<smiles>COCCOCCOCCOC</smiles> 
(3) は張力のある環が開環と同時に鎖を形成す ろ場合であり (1)の二重結合を張力のかかつた 員環と考へれば (1) の部類之同一に考へ得られ る。(1)(2)共に現在宲分子合成の骨子をなす型態 であるポリアミドは（2）の型態に入る縮合重合物 である。

$$
\text { ナイロン }
$$

ポリアミド生成型式は(2)の(例以外)に20-ア ミ)酸の自家重合をる考へられる

$$
\begin{aligned}
& \mathrm{NH} \cdot\left(\mathrm{CH}_{2}\right)_{n} \cdot \mathrm{COOH} \rightarrow \cdots \cdot \mathrm{NH}_{2}\left(\mathrm{CH}_{2}\right)_{n} \mathrm{CO} \\
& \left.\mathrm{NH} \cdot \mathrm{CH}_{2}\right)_{n} \mathrm{CO}-\cdots . . .
\end{aligned}
$$

一般にかかる二官能顉狀化合物間の反應は環を生 成すべきか互大なる長鋇を生すべきか，現在は既 に常識となれるての間題が有機化兒に於て不徽底 なる想像的結論のまま捨てられて居た。

Carothersはこの間題を取り上げ明確なる理論? のものに統制する賽驗 に於て解決を行つた、こ の研究は幾多の貴重なる學術的貢锹でありナイロ ンを世に㷟つたととで有名である，二官能顉狀化 合物間の反應は或ろ特定の位㯰的制約のない限り 鎮狀化合物をつくろのが一般である。
Carothessはこの研究を始めるに際し頭初より ポリアミドを用ひたのではない同氏等つポリェス テルに於ける研究は特に高分子形成に從つて高分 子的性質を徐々に示せる所歴史的に興味深いから ここに紹介し Carothers自身ナイロンに關する基 磷研究の全然發表されて居ない㗪みを補.う.ここに Lたh。

Carothers, Natta ${ }^{4}$ is $w$-Hydroxyundecanoic acid を加熱自家エステル化反應を進行せしめ次第 に亩分子のボリステルを得て居る。可紡性ある ボリエステルを得るためには重合の進展ととるに 反應生成揮發物 $\left(\mathrm{H}_{2} \mathrm{O}\right)$ の除去の困䧳其つ他つ理由 により分子蒸溜つ原理を用ひねばならなかつた。 得られた次表はボリェステルの精製後の性领であ り分子量は滴定により末端基法より求められて居 ろが分子鑟長の聕大之可紡性冷延伸の關係が興味 梁く見られる分子量 5670 に於て紡絲か： 9330 に 於て冷延伸が可能さなり可紡性は 16900 まで增 加して居る Carothers Natt は同論交に 於て可撓 性のある配位を持つた可なりの强い緎維を合成物 質から得た最初の一例であると信すと述へてる ろ。 fensile strength $13.1 \mathrm{~kg} / \mathrm{mm}^{2}$ は $1.36 \mathrm{~g} /$ denier

\begin{tabular}{|c|c|c|c|c|}
\hline 分子是 & 分子艮 $A$ & 酸㫮 & $d_{4}=5$ & 可紡性 \\
\hline 780 & 60 & $66-67$ & 1.0957 & $+z$ \\
\hline 1720 & 123 & $72-74$ & 1.0935 & +2 \\
\hline 3190 & . 188 & $74-75$ & 1.0877 & +2 \\
\hline 4170 & 313 & $74-76$ & 1.0814 & +2 \\
\hline
\end{tabular}
にあたる。ボリェステルは㪀化點低く且化學的試 vory-undecanaic acid 近合體

\begin{tabular}{rrrl}
5670 & 440 & $73-75$ & 1.0751 \\
7330 & 570 & $74-75$ & 1.0715 \\
9330 & 730 & $75-76$ & 1.0668 \\
16200 & 1320 & $77-78$ & 1.0627 \\
20700 & 1620 & $77-78$ & 1.0632 \\
25200 & 1970 & $75-78$ & 1.0621 \\
\hline
\end{tabular}

1) チイソンャナートとデカルボン酸に上る附加的車 合によるポリアミドの生成, 星野敏婎, 岩会。

2) An Introduction to the General theory of Condensation Polymers Jeurn. Am. Chem. Soc. 51, 2548-

\begin{tabular}{|c|c|c|}
\hline 非常に整䋘維 & 冾延伸は出来秃い & \\
\hline 艮瑊䧽 & 冾延伸は出来ない & 进茯晹し \\
\hline 艮瀻維 & 椧延伸可能 & 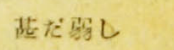 \\
\hline 紀絲性良好 & 冾延伸 & $13.1 \mathrm{~kg} / \mathrm{mm}^{2}$ \\
\hline 新綵困蒦 & 冷延伸察是 & $12.8 \mathrm{~kg} / \mathrm{mm}^{2}$ \\
\hline $210^{\circ}$ 以上で可新性 & 冾延伸 & $7.0 \mathrm{~kg} / \mathrm{mmo}^{2}$ \\
\hline
\end{tabular}
59 (1927) Polymerisation. W. H. Corothers. Chem. Rew. 8, 353-426 (1931).

3) Carother 及び協同酼者 Stugies on Polymerizat en and Ring Formation 1 28 佛 1929-36 米四化 學雜誌所武 H.'Mark, G. S. Whitby Collected Papers of W. H. Carothers on high Polgmeric Substances. Interscience pub, ine. New York 1940.

4) W. H. Carothers, Van Niatta Jour. Am. Chem. Soc, $1933 \mathbf{5 5}, 4714$. 


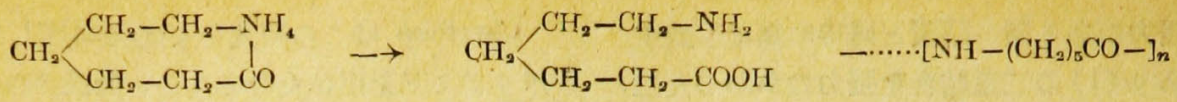

藥に抵抗力小さく事筫現在に於ても賽用にされて 居ない樣であるが彼等が Super Polymer に於て 將來有用なる合成繊維の出現を確信したことは云 ふっまでもなく想像される, Polyanide に關する學 術報告は次示の一篇に見られる。Polyamides and Mixed Polyester-Polyamides ${ }^{1)}$ 其處几於て $\varepsilon$-Aminocaproic acide の車合，アミノ酸二監基酸，グリ コール三者つ反應によろ混合ポリアミドーポリエ スラルが取扱はれて居る の重合は當時まだ纎維形成へまでには成功してる ないがナイロンの出現後とのポリアミドは新に重 要なるポリアミドとして重視されるに至つた。

1938 年 9 月 20 日（昭和 13 年）ナイロンがヂ ユポン社つ特許 (U. S. P. 2130948) てなり蜘蛛つ 糸よりる細く鋼鐵よりる强い繊維として宣傅され カロサーズ及び協同研究者の研究が今而新しく認 識され吾國朝野を警かしたのは有名である。ナイ ロンはへキサメチレンヂフミンとアヂピン酸なる 二監基酸，二酸艋基つスーパーポリアミドであつ たのである。

\section{一般ポリアミト}

Carothers の研究により一般に二官能鎻狀化合 物を相互に反應せしめ得らるる重合體は線狀化合 物であり縮合を强度に進める时は所謂高分子的特 質を明暸に示す所謂スーパーポリマーに變化する てとは既て述へた處でありナイロンはスーパーポ リアミドであることも既に述べた重合法は理論上 ポリエステルと異なる所はなく而もボリアミドの 場合エステル生成反應に比較し?ミド結合生成平 衡恒數の甚た大なるこよは縮合の容易さを示する のに他ならない2，事實は縮合物が高融點であり 高溫熔融狀態に於て酸化に對して着色及び二次的 なる變化を受け易い等つ外的困難のために無色の

1) W. H. Corothers, J. W. Hill J. A. C. S. 54, 1566-69 (1932).

2) G, V. Schuls: Z. physir. Chem [A] 182, 127 (1938).
絹継狀ナイロンが商品化されるまでには相當の困 難があつただらうと想像される。とのととは重合 に關する特許, 熔融紡絲に關する特許, 等重合度 安定劑酸化防止に關する特許等に於て推察し難く ない゙่現在吾國に於ても之等の諸點は克服され立 派な試作品が試供さるるに至つて居る。

Caprolactam の重合は水の存在を必要とする。 星野 (孝平) 氏の研究に低れば全く乾燥せるラク 夕ム單量體は高い溫度に加熱するもポリカプロラ クタムを與へない。ラクタムの加水分解によるを一 アミノカプロン酸の生成が重合の第一階梯にある ことが想像される゙)。

二官能鎖化合物としてここに多種の $\mathrm{RR}^{\prime}$ の變 化があり

$$
\begin{aligned}
& X-R-X+Y-R^{\prime}-Y \rightarrow \\
& -X-R-Z-R^{\prime}-Z-\cdots \cdots X Y \rightarrow Z
\end{aligned}
$$

ことに多種多樣の線狀ポリアミドを生成すべき であり, 又原料に於ける官能基をこれ以上に增す ことにより三次元的なる熱硬化性のポリアミドを 生成すべきである。今とてに之等て就き詳細なる 㸴究を記し且つ其の諸性質を列記してポリアミド

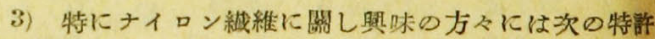
があるから參照されたい。

1) Nylon 全般: U.S.P. $2,130,523,2.130948$.

D) 重合: U.S.P. $2,130,948$, E.P. 461,236 (Xylenal の如き溶媒中の生合法, 無溶媒生合法)。 U.S.P. $2,163,548,2.163636$, N.P. 142,082 (加 水生合法)。

U.S.P. $2,176,074$ (アルュール中の生合法)。 N.P. $1,54,840$ (著者：高度黃空下二段生合 法)。

八) 粘度安定劑及安定法，酸化防止劑； E. P $495,790,461,273$,

$\Rightarrow$ 可望㧩の添加; U.S.P. 2,214397, 2,214.402, $2,214,405,2,214.442$ (掘點降下濟)。

小) 揢蛬紡絲法; N.P. $140,741,143.744$.

へ) 後處理；2,212.770, 2,212,772, 特许公告昭和 16 年第 3603 號公報 (冷伸張法) U.S. P. 2177637 (フォルマリン處理)。

4) U.S.P. $2.241,321$ (IG.), U.S.P. 2.241,322 (du Pont) 田代, 小田理䂠鱼報 20,6 及 12 號, 星野 (孝) 野一色 相川：日化 62 (昭和 16 年) 12 號。 
樹脂概觀を果すべきであるが，未踏の分野多く其 の性質る明膫ならざるもの多い。特許に於て散見 さるるものを絓めるによどめる1)

(1) ポリメチレンヂフミンとボリメチレンヂカ ルボン酸縮合物例へばへキサメチレンヂアミン上 アヂピン酸の縮合物ナイロンが一例であり，フエ フール類, 低級脂肪酸以外の溶媒に不溶にして熔 骶紡絲により優秀はる㵶維を與へる構造單位の原 子數戸9(後述)に於て有用となる工業的に最有用 なるポリアミドの一つである。

(2)(1)例のポリメチレン顉に分岐を有ずるの 洌へば B-メチルアヂピン酸 3-メチルヘキサメ チレンチアミン又は第二級のヂアミン例へば $\mathrm{N}$, N'ーチメチルペンタメチレンヂアミン等を縮合の 一組成とするポリアミドで之等は他の線狀高分子 化合物より類推される如く溶解性廣篹圍となり䨋 質又は粘秱の液體のもの多く, 紡緗性は (1)に比 し劣る。

(3) 鎖中にチクロヘキサン核又はチクロベンタ 核を有するもの例へばへキサヒドロテレフター 几酸チクロペンタンチカカポン酸等を縮合一成分 とするポリアミドで (1) 同樣紡綵性ある高縮合物 をつくろと云はる。

（4）鋇中に芳香核を有するもの例へば P-フェ ンレンヂ醋酸 P-キジリレンヂアミン等を縮合成 分とするポリアミドにして (1) と同栐紡絲性を有 すと云はれてるるが概して脆いものが多く核に官 能基が近づくに從つて其の傾向は强く現はれる。

(5) 鎖中に酸系又は硫黃の如きへキロ原子叉は 原子團を(- $\left.\mathrm{S}-,-\mathrm{O}--\mathrm{SO}_{2}-\right)$ 鎖員として有す るもの例へばチグリュール酸 $\beta, \beta^{\prime}$ ーチアミノチュ チルエーテル，チチオグリコール酸等を縮合一成 分とせるポリアミドにして之等は溶解度厮範圍と なり織維となし得るが一般に紡絲性は劣る場合が 多的。

1) ナイロン系ボりアミド U.S.P. 2,071,253 2,130,583, 2130,948 .

特然なる線狀ポリアミド U.S.P. 2,158,064 2,174,619, $2,191,556$, E.P. 487.734

三次元的粠造を取り得るボりアミト U.S.P. 2,174,619 $2,149,273$
以上は線狀ポリアミドを對照とし分類せるるの にして從來の繊維を對照とせる研究は今後其の灰 向を他面へる發展せしさべきであり，未踏つ應用 分野は拓かるべき可能性がある。

\section{三次元的ポリアミト゚}

上に述べるる如く縮合成分の官能基つ百に增加 は終局に於て熱硬化性三次元的ポリアミト゚を生成 する。(arothers) は非ベンゼン型二重結合を含む ポリアミドとしてマレイン酸フタール酸，アセ チレンヂカルポン酸を縮合組成としたボリアミト に就て述へてるる。之等は低融點にして種々の有 機溶剂に可溶となり更に加熱により不溶不熔つ樹 脂に督化する性質を有して居る。

ナイロンの如く熔融性であり軟化點の高き丞め （ナイロンはこの點左程缺點とはならない）溶解 溶剂が少なく限定されて居ろ場合熱硬化性にして 且つ溶解篹園の掂い樹脂は特殊なる成型用樹脂乃 至鉒裝用の樹脂として期待される現在この方面の 研究は僅か Carothersによつて手づけられた以外 に發表がなく將來の研究を俟つるのである。

Carothers はェチレントリアミン $\mathrm{H}_{2} \mathrm{NCH}_{2} \mathrm{NH}$ $\mathrm{CH}_{2} \mathrm{CH}_{2} \mathrm{NH}$ 、トリェチルテトラアミン $\mathrm{H}_{2} \mathrm{~N}$ : $\left(\mathrm{CH}_{2}\right)_{2} \mathrm{NH}\left(\mathrm{CH}_{2}\right)_{2} \mathrm{NH}\left(\mathrm{CH}_{2}\right)_{2} \mathrm{NH}_{2}$ の如き反應基 三個以上を有するアミン,を以つて二留酸を縮合 せしめボリアミドを教化點の低き樹脂样物質とし て得てねろ[例,アチビン酸ーエチレントリアミン] 一般に溶解性範圍廣く或る種のるのは水溶性であ

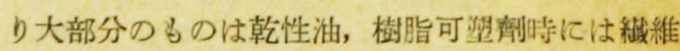

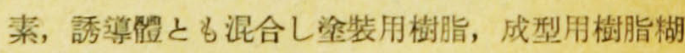
料接着劑等つ製造原料に用ひらる, 熱硬化性であ ることは勿論である゙3。

ここにボリアミドと近緣關係にあるボリチォア ミドに就て迅忍るにこの物は - $\mathrm{NHCO}$ - 基の 酸素の替りに硫黄を含むるのである。ポリアミド に比較して特に顯著なる性質は歭告されてるない 製法としてはチアミンに二硫化炭素を作用せしさ

2) Carothers U.S.P. 2,174.619 (前出)。

3) Carothers U.S.P. 2,149,273 (前出)。 
る法" ヂニトリル，ヂアミン，硫化水素の加熱縮 合による法りがある。

\section{ポリアミド樹脂の性質}

フミド結合の週期的繰返さるる線狀ポリアミド に於ては其の示す性質がアミド結合に支配さるる ことは云ふまでもなん，化學的にアミド結合がエ スラル結合に比慗し安定であり且其の有する分子 結合の形式は水秦結合を示し大なる分子凝集力之 ふつて示されて居る。

\begin{tabular}{|c|c|c|c|}
\hline \multicolumn{2}{|c|}{ 原子国 分子䟿紧力 } & 原于图 & 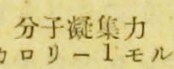 \\
\hline $\left.\begin{array}{l}-\mathrm{CH}_{3} \\
=\mathrm{CH}_{3}\end{array}\right\}$ & 1780 & $-\mathrm{NH}_{2}$ & 3530 \\
\hline $\left.\begin{array}{l}-\mathrm{CH}_{2}- \\
=\mathrm{CH}-\end{array}\right\}$ & 990 & $-\mathrm{Cl}$ & 3400 \\
\hline$-\mathrm{CH}-$ & 380 & $-F$ & 2060 \\
\hline$-0-$ & 1630 & $-\mathrm{Br}$ & 4300 \\
\hline$-\mathrm{OH}-$ & 7250 & $-J$ & 5040 \\
\hline$=\mathrm{CO}$ & 4270 & $-\mathrm{NO}_{2}$ & 7200 \\
\hline - СНO & 4700 & $-\mathrm{SH}$ & 4250 \\
\hline$-\mathrm{COOH}$ & 8970 & $-\mathrm{CONH}_{2}$ & 13200 \\
\hline$-\mathrm{COOCH}_{3}$ & 5600 & $-\mathrm{CONH}-$ & 16200 \\
\hline$-\mathrm{COOC}_{2} \mathrm{H}_{5}$ & 6230 & & \\
\hline
\end{tabular}

かく分子凝集力の大なるこさは瀻維爿に高度に
配位せる時䊼維こして大なる强靶性を附與して得 る。ナイロンの强鞄性及び而就性は重合度と共に これによるものと解釋される，一方汃く分子㠜集 カの大なる原因が或る種の短鎻ヂアミンーヂカル ボン酸より有用なるポリアミドを得ることを阻ん で居る原因でもある゙う。以は一般諭にして詳細 に立入つた Dataがない。唯ここに硎究の進んで みるナイロン，カプラミド重縮合物に就て其の性 質を而も主として繊維として配位された，形に於 て調へられた数值を列與して参考己したい。

熔融紡絲を行ひ且つ冷延伸なる操作を行つて得 られた高度に配位せる繊維は絹よりも强い其の機 械的性頎の內摩擦强力に於て著しく優れ彈性ヤン グ率に於て特徽を示して居る。化學的性質も又鑍 を檴成将るパラフイン鎻さアミド結合に大きく支 配されて居る。耐水, 耐アルカリー性にして强ア ルカリーと者ても强力に變化を示さない耐酸性に 於ても人綟の 100 倍も强いことが報告されてる ろ。日光, 紫外線によく耐へ, 又耐細菌性繊維之 して利用する場合の一特色をなす。且又耐油性甚 だ良好で電気的性質としては高周波縃緣性に於て は劣ろが絕緣耐力は $1 \mathrm{~mm}$ 厚さに對し $126,000 \mathrm{~V}$ 物理的性啠 (Clayton)

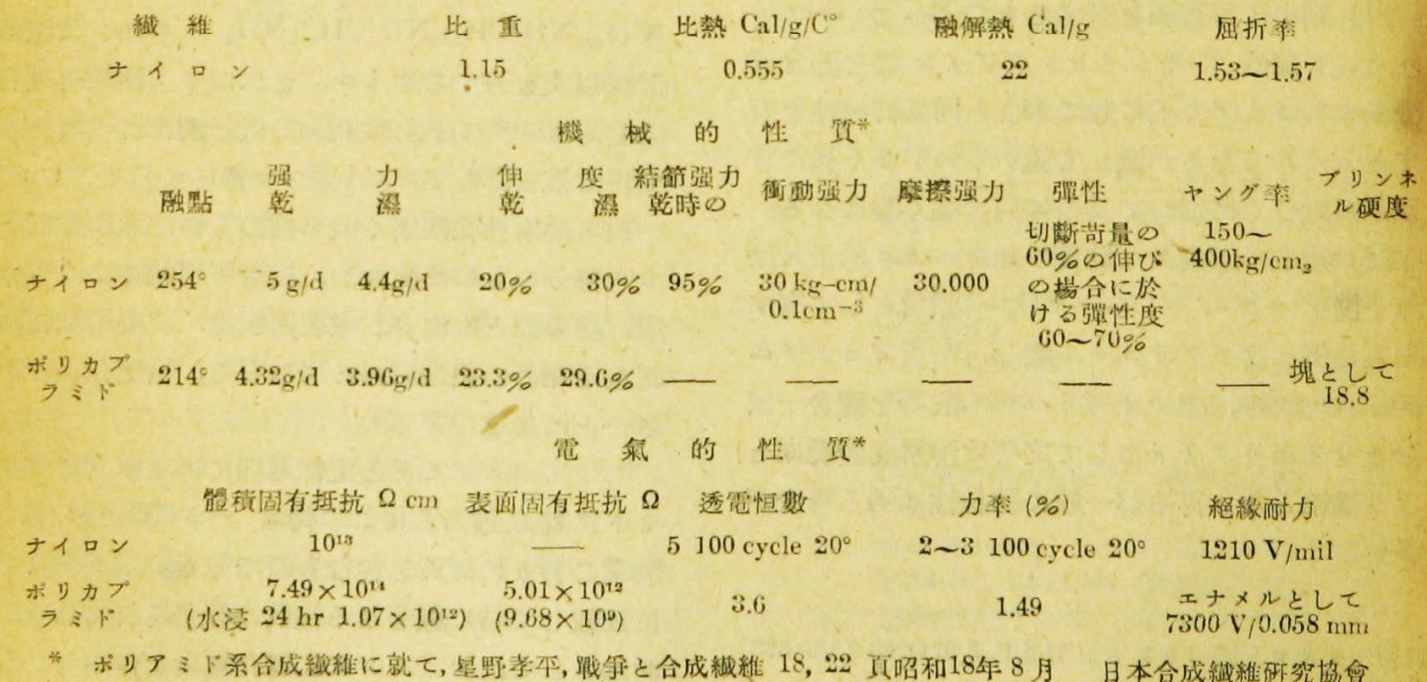

1) 小田目代 N.P. P. 143,158. 理砄稞報, 炤 15 第20 輁第 6 號.

2) dupont U.S.P. 2,201,172.
3) この點に關しては後に原料の問題に於て述へてこ では立入らせい。 
に當り電線の被覆として特殊なる用途が吾國に於 て考へられて居る。

用 途今次の世界大戰施期としてナイロン出 現つ當初に於て宣傳されたものと用途にも大いな る變遷をらけたであらう。生綃生產しない米國に 热ては生線絹製品の軍事的用途の代品として民需 さ差控へ增產に急いでるることは想像し 難くな い*。幸ひ吾國は生絲の過剩にる生產し得る能力 を有しかかる方面への考慮を要せざる立場にあり 全力を上げてかかかる新重合物の軍事的利用に特質 を極度に利用すべきである。現在吾國に於て小規

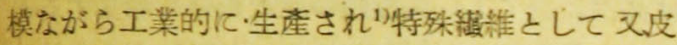
膜として電線被覆とし接着劑として軍事的用途を 見出され，益々多方面に利用が考へられつつある ことは喜ばしい。

\section{合成及び原料}

現在ナイロン原料がフェノールを原料とし次示 A の經路に於て合成されカプラミド高縮合體が
次示 $\mathrm{B}$ の經路を經て合成されてるる。これは米 國に於ても然りであらうことは原料に關する特許 よりも裹書さるる所である。

これらの製造工程に關しては吾國に於て諸々の 大嶨及び研究室に於て研究され筫驗室的な研究は 一應檢討し盡された2)現在東洋レイヨン 種村功太 郎氏京都帝大小田良平氏により中規慔の工業化實 驗が行はれて居り前者て於ては其の彆品が一部釣 綵其の他となり武供されて居る。 ナイロンポリカプラミト縮合绸は㱠んど性質の類 似し且兩者原料を等しくせる點何れを製造工程と して何れをつくろかは問題であるが中間零驗を經 て見なければ直ちに優劣は速斷し得ざる所であ る。特にこれが戰時狀態に於ては然りである。

戰時石炭酸つ需要つ激增は腺測し得る所であり 特に航空機製造方面に多大の用途あるに於てをや である。要は鐵つ增趎にともなふタールの增成に あれども猊浪原料に就てる一考を要す所である。

稲つて一般ポリアミド生成原料に就て考ふるに。
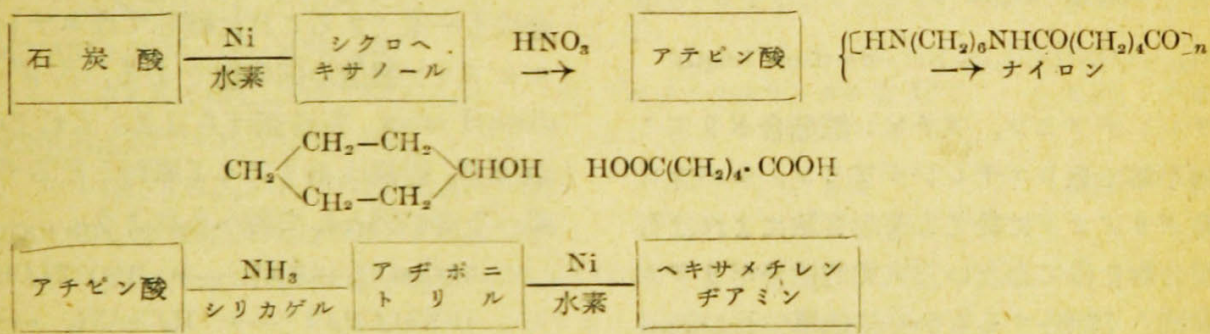

$$
\mathrm{NC}\left(\mathrm{CH}_{2}\right)_{4} \mathrm{CN} \quad \mathrm{HN}\left(\mathrm{CH}_{2}\right)_{6} \mathrm{NH}_{2}
$$

(B)
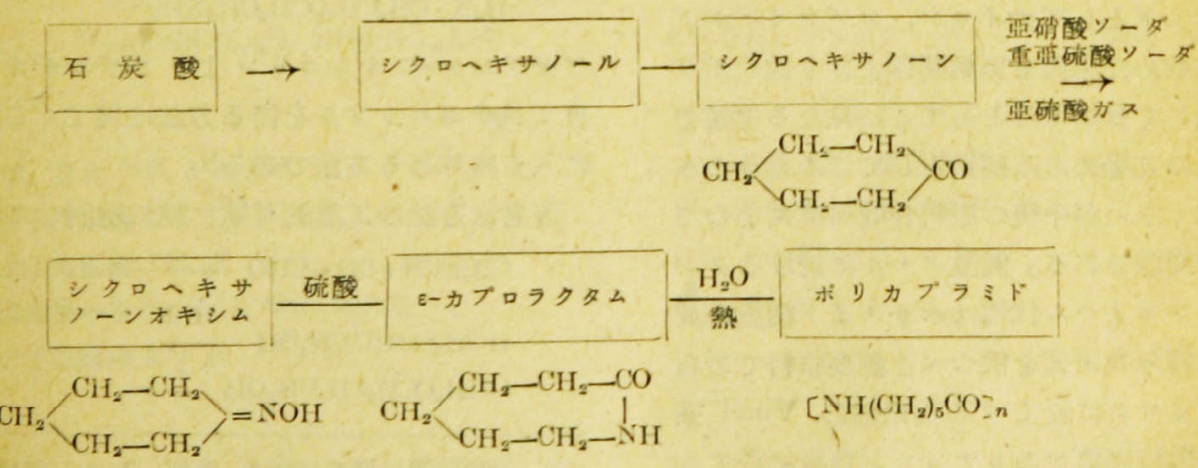

1)外國に於けるポリアミド商品名 I. G. 站 Igamid A, Igamid 1'. Igamid 6A Igamid 85 B. Rerlon. 內容 の詳細は不明。米國に於けるナイロンの年着は 1942 年 來 2000 萬封度の豫定, 其の後詳細は不明。
2)站問題に關しては日本合成䋐維研究協會が第一分 科會に於こ取り上げ研究促通に大いなる面㓺を行つた。

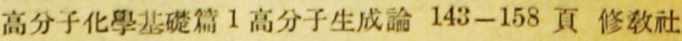
㝜院東京。 
原料ヂアミン，二監基酸はこれが適度の熔融點及 び溶解性を示すためには䥊長に或る制限つ存在す ることである既述の特許にも記载されたる如く有 用なる重合物を得るには構造單位長 (Unit length) が 9 又は其以上を必要とする，これは瀻維を對照 そ立る言であららが一般樹脂にる一應あてはまる ものである。

\begin{tabular}{|c|c|c|c|c|}
\hline ヂアミン & 二礐萑酸 & 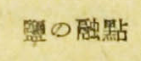 & $\begin{array}{l}\text { 稦造 } \\
\text { 單位长 }\end{array}$ & 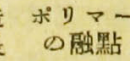 \\
\hline Aethylen & Adipic & & 10 & 不溶 不烃 \\
\hline Aethylen & Sebasic & & 14 & $254^{\circ} \mathrm{C}$ \\
\hline Hexamethylen & Adipic & $183-184$ & 14 & $254^{\circ} \mathrm{C}$ \\
\hline Tetramethylen & Azelaic & $175-176$ & 15 & $223^{\circ} \mathrm{C}$ \\
\hline Hexamethylen & Sebasic & $170-172$ & 18 & $209^{\circ} \mathrm{C}$ \\
\hline Octamethylen & Sebosic & $164-165$ & 20 & $197^{\circ} \mathrm{C}$ \\
\hline Decamethylen & Sebosic & & 22 & $194^{\circ} \mathrm{C}$ \\
\hline 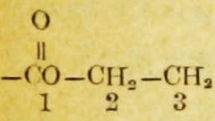 & $-\frac{O}{11}$ & $-\underset{1}{\mathrm{NH}}-\underset{2}{\mathrm{CH}_{2}}$ & $\begin{array}{c}\mathrm{C}_{2}-\mathrm{CH} \\
3\end{array}$ & $-\frac{\mathrm{NH}}{4}$ \\
\hline
\end{tabular}

$\rightarrow \mathrm{OC}\left(\mathrm{CH}_{2}\right)_{2}-\mathrm{CON} \mathrm{H}\left(\mathrm{CH}_{2}\right)_{2}-\mathrm{NH}-8=$ (Unit length)

實際エチレンヂアミン，アチピン酸縮合ポリアミ ドは不溶不熔でありエチレンヂアミン，セバチン 酸の縮合ボリアミドに於ても著者賽驗によれば有 用なる重合物を得てるない三次元的縮合ポリアミ ドを今しばらく除外するるかく檏造單位長の制限 はポリアミド合成原料に於ける重要なる险路であ る。ポりアミドそしてナイロン，カプラミドが工 業的成功を收めた原因も原料問題にあり他のポリ アミドが新しく登場するとしても特殊なる用途を 有する特別つ立場にある樹脂としてであらうこと は想像に難くなんか゚今後の原料合成侀究によつて 打開すぺき問題である。低溫タールに於けるクレ ゾール類のフェノール代用はポリアミド樹脂合成 原料として將來の研究を俟つべき重要原料であら う。現在ナイロンに於てすら悦ほ他つVinyl 系 樹脂に比し數倍高價でありナイロン自身に於ても 猶法合成法つ研究を必要とする。

上述鑟長つ制限を考虑に入れ二酸基酸, 二酸監 基の合成はベンゾール核開環による方法（ナイロ
ン，カプラミド）以外に如何なる方法及び原料が 存在するであららが，脂肪酸に例を取るも現在こ れが $w$-位の酸化は不可能であり僅に不飽和脂肪 酸の硝酸攵っナヂン觸媒酸化又はとマシ油等の特 異なるつルカリ一酸化が問題となるのみである。 脂肪酸原料は安價とは云へない。吾が南邦の開拓 に從つて石油系炭化水素の原料が將來問題となり 得るブタンヘキサンの氣相硝化反應は現在 $\alpha-w$ ニトロ化合物を與へて居ない。ブチルクロリドの 監素化による1,4-ヂクロールブタンの製法は生成 する異性䌡む少く Vaughan Russ の研究によれ ば高溫に於て 1,4-異性體の生成割合を增加すると 云ふ，異性體つ利用如何によつて興味ある方法と なるか子知れない。

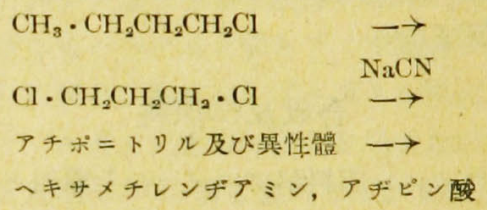

低分子化合物の融合による二官能鑬狀化合物の 合成も一案であるこれに閭してはエチレンクロー ルヒドリン製造の副㡾物である, $\beta, \beta^{\prime}$-di-chlordiathyl ather 等が揭げられる。これの監素原子 の $\mathrm{NH}_{2}$ 毕換はポリアミド原料となるヂアミンを 與へる等が例として考へられよう。

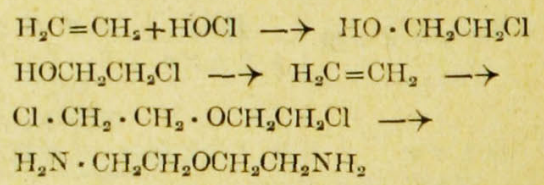
經てアチポ =トリルを得る方法は同じくこの部類 に入る興味ある方法である1”。

萻者は方法つ工業的可能に就て檢討してるる゚。

$$
\begin{aligned}
& \mathrm{CH} \equiv \mathrm{CH}+2 \mathrm{H}-\mathrm{CHO} \longrightarrow \\
& \mathrm{HCl} \\
& \mathrm{HOH}_{2} \mathrm{CC} \equiv \mathrm{CCH}_{2} \mathrm{OH} \stackrel{\mathrm{H}}{\longrightarrow} \\
& \mathrm{OHH}_{2} \mathrm{CCH}_{2} \mathrm{CH}_{2} \mathrm{CH}_{2} \mathrm{OH} \longrightarrow
\end{aligned}
$$

1) この問题に就ては著者, 萩原, $\alpha, v$ 二官能錙狀化

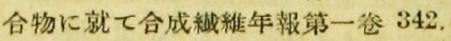

$$
\text { U. S. P. } 2.222,2302 \text {. }
$$

2) 著者 龍谷交吉, 日本合成䋐維研究協會䜅㴼會, 昭和 18 年 10 月 4 日大阪維業俱樂部。 


$$
\begin{aligned}
& \mathrm{Cl} \cdot \mathrm{CH}_{2} \cdot \mathrm{CH}_{2} \mathrm{CH}_{2} \mathrm{CH}_{2} \mathrm{Cl} \stackrel{\mathrm{NaCN}}{\longrightarrow} \\
& \mathrm{CN}\left(\mathrm{CH}_{2}\right)_{4} \mathrm{CN}\left\langle\begin{array}{l}
\text { アヂピン酸 } \\
\text { 人サメチレンギアミン }
\end{array}\right.
\end{aligned}
$$

以上はポリアミドに關する慜見を行つた論文であ ろが初頭に述べた如く新興樹脂であり未踏未調查

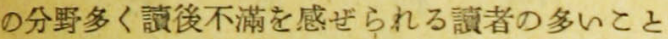
そ思ふ大方今後の發達に寄與あらんととを願ふ次 第である。吾國の縮合系合成高分子の研究はボリ
アミドに限られない。次に本那に於ける縮合系高 分子合成研究に於て現行されて居る縮合形式の數 例を簡單に表示し以つて讀者の參考に資すると同 時にポリアミドと近緗なる關係にある樹脂に於て も盛に合成研究が行はれつつあることに就き蓝者 の注意を喚起したい。(昭和 19 年 6 月 2 日)

（大阪帝國大學敏授毒業科學研究所只・理博)

\section{反應形式}

1. $\mathrm{CS}_{2}+\mathrm{H}_{2} \mathrm{~N} \cdot\left(\mathrm{CH}_{2}\right)_{n} \mathrm{NH}_{2}$ $-\left[\mathrm{NH}\left(\mathrm{CH}_{2}\right) \mathrm{NHCS}\right]$

2. $\mathrm{SCN}\left(\mathrm{CH}_{2}\right)_{n} \mathrm{NCS}+\mathrm{H}_{2} \mathrm{~N}\left(\mathrm{CH}_{2}\right)_{m} \mathrm{NH}$ $-\left[\mathrm{SCNH}\left(\mathrm{CH}_{2}\right)_{n} \mathrm{NHCS}\left(\mathrm{CH}_{2}\right)_{m} \mathrm{NH}\right]$

メポりアミド采

メボリチオアミド采

3. $\mathrm{OCN}\left(\mathrm{CH}_{2}\right)_{n} \mathrm{NCO}+\mathrm{HO} \cdot\left(\mathrm{CH}_{2}\right)_{m} \mathrm{OH}$ $-\left[\mathrm{NH} \cdot \mathrm{COO}\left(\mathrm{CH}_{2}\right)_{m} \cdot \mathrm{OOCNH}\left(\mathrm{CH}_{2}\right)_{n}\right]$

4. $\mathrm{H}_{2} \mathrm{O}_{2} \mathrm{O}_{2} \mathrm{CHN}\left(\mathrm{CH}_{2}\right)_{n} \mathrm{NHCOOC}_{2} \mathrm{H}_{5}+\mathrm{HO}\left(\mathrm{CH}_{2}\right)_{m} \mathrm{OH}$

5. $\mathrm{SCN}\left(\mathrm{CH}_{2}\right)_{n} \cdot \mathrm{NCS}+\mathrm{HO}\left(\mathrm{CH}_{2}\right)_{m} \cdot \mathrm{OH} \longrightarrow$ $-\left[\mathrm{SCNH}\left(\mathrm{CH}_{2}\right)_{n} \mathrm{NHCSO}\left(\mathrm{CH}_{2}\right)_{m} \mathrm{O}\right]$

6. $\mathrm{OCN}\left(\mathrm{CH}_{2}\right)_{n} \mathrm{NCO}+\mathrm{HS} \cdot\left(\mathrm{CH}_{2}\right)_{m} \mathrm{SH}$

$$
-\left[\mathrm{OCNH}\left(\mathrm{CH}_{2}\right)_{n} \mathrm{NHCOS}\left(\mathrm{CH}_{2}\right)_{n} \mathrm{~S}\right]
$$

7. $\mathrm{OCN}\left(\mathrm{CH}_{2}\right)_{n} \mathrm{NCO}+\mathrm{H}_{2} \mathrm{~N}\left(\mathrm{CH}_{2}\right)_{m} \mathrm{NH}_{2}$

$$
-\left[\mathrm{HN}\left(\mathrm{CH}_{2}\right)_{n} \mathrm{NHCONH}\left(\mathrm{CH}_{2}\right)_{m} \mathrm{NHCO}\right]
$$

8. $\mathrm{HOOC}\left(\mathrm{CH}_{2}\right)_{5} \mathrm{NHO}_{2} \mathrm{~S}\left(\mathrm{CH}_{2}\right)_{4} \mathrm{SO}_{2} \mathrm{NH}\left(\mathrm{CH}_{2}\right)_{5} \mathrm{COOH}$ $-\left[\mathrm{OC}\left(\mathrm{CH}_{2}\right)_{5} \mathrm{NHOS}\left(\mathrm{CH}_{2}\right)_{n} \mathrm{SO}_{2} \mathrm{NH}\left(\mathrm{CH}_{2}\right)_{5} \mathrm{CONH}\left(\mathrm{CH}_{2}\right)_{n} \mathrm{NH}\right]^{2}$

メポりカルポンアミト・スルフォンアミト 村橋, 激潀

9. $\mathrm{O}_{2} \mathrm{~N} \cdot \square-\mathrm{O} \cdot \mathrm{O}_{2} \mathrm{~S}_{(}\left(\mathrm{CH}_{2}\right)_{n} \cdot \mathrm{SO}_{2} \mathrm{O} \cdot-\mathrm{NO}_{2}+\mathrm{H}_{2} \mathrm{~N} \cdot\left(\mathrm{CH}_{2}\right)_{m} \mathrm{NH}_{2}$

$$
-\left[\mathrm{O}_{2} \mathrm{~S}\left(\mathrm{CH}_{2}\right)_{n} \mathrm{SO}_{2} \mathrm{NH}\left(\mathrm{CH}_{2}\right)_{m} \mathrm{NH}\right]-
$$

メボリスルフォンアミド

文

\section{献}

(1) 小田, 目代 NP. 143, 158.

(6) 高分子生成論 212 页

(2) 高分子生成諭 208 頁

(7) 高分子生成論 192 页

(3) 高分子生成論 195 頁

(8) 工化末刊

(4) 合成織䊒年報第一告 $1.333-341$ 頁

(9) 工化末刊

\section{研究者名}

小田, 目代

星野, 岩合

星野, 岩合 村橋, 中西

星野, 岩合

星野, 岩合

星里, 岩合

村橋, 消瀑

(5) 高分子生成論 212 頁 